\section{Pastiches, plágios e edições falsas}

\author{
ILZA MATIAS DE SOUZA
}

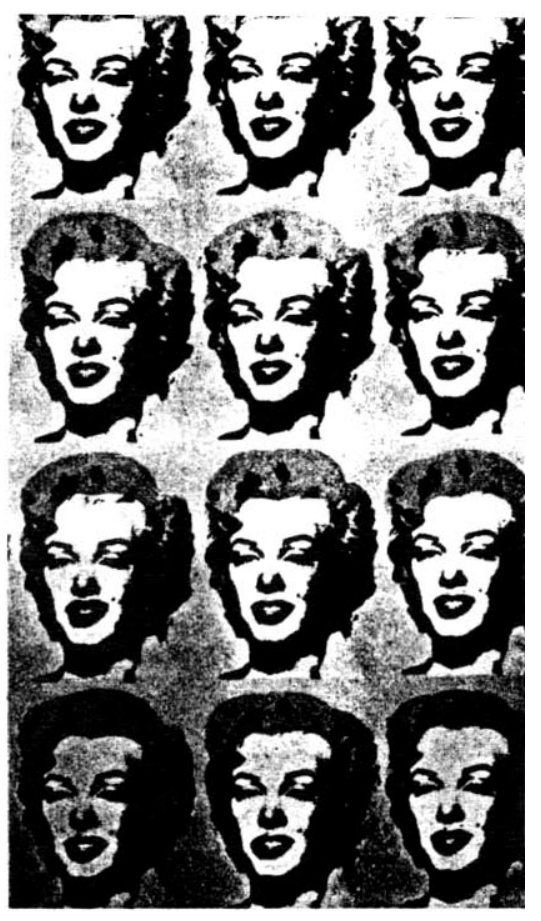

A autoria é, no Nome falso: homenagem a Roberto Arlt, de Ricardo Piglia, o mecanismo que põe em funcionamento a máquina de fabricar moedas imaginárias.

Escritor de súmulas literárias, o narrador vê imiscuir-se, na sua atividade de copista e compilador da obra de outros, a figura do demônio da transcrição infiel, Saul Kostia. Este vive no ócio e na embriaguez, e instala desorientação na SCRIPTORIA, assinando e apresentando em seu nome o trabalho literário de Roberto Arlt. Rapinante e plagiário, Kostia exclui a produção intelectual e literária do regime de propriedade. Faz do plágio e da rapinagem os recursos técnicos do comércio com as coisas literárias. Recebe dinheiro de Piglia, em troca do texto inédito de Arlt. Sua economia pelo avesso arruína o sistema de apropriação regulador da autoria.

Kostia e Piglia colocam em jogo a atividade artística articulada com a circulação da moeda, numa economia de prestŕgio. Tal economia dá lugar a uma forma dissimulada e astuciosa de apropriação da produção baseada na rapina, no roubo.

O trabalhador literário mostra-se um imitador da obra alheia, um falsário. Vende o trabalho do outro. Assina a obra alheia. Ofício de ladrões que tiram do ócio social os meios de vida. Piglia narra essa história ilícita. Transforma-se no narrador de sua própria diligência falsa.

Kostia, com seu "dedo ocioso", exerce a escrita, tornando-a um tratado comercial, negócio escuso. Deslegitima o princípio da escrituração: contratar por meio de escritura. Contrato que parecia, ao dedicado resgatador da obra de Arlt, Ricardo Piglia, ter sido firmado entre os dois. Toma conhecimento de que o falsificador publicara o texto de Arlt sob seu nome. O Nome falso desqualifica a escrita enquanto documento autêntico de um contrato. No maquinismo engenhoso da scriptoria proliferam os textos, cuja autenticidade não se pode provar. Textos apócrifos desestabilizadores de originais e originalidades. Enlouquecem a investigação sobre a existência real do autor ou de autores e de seus originais.

Não há mais como chamar à autoria, a não ser como processo textual. O direito autoral (exercido pelo autor ou por seus descendentes sobre suas obras, com respeito à publicação, tradução, venda, etc.) torna-se uma negociação ilícita face à condição pública e coletiva da obra literária.

Morto e sem descendentes, o autor não tem mais domínio sobre sua obra. Esta circula sem controle, sendo objeto potencial de apropriação. De uma certa maneira, ao dar a obra a público, o autor entrega ou renuncia aos direitos e à propriedade. Isso inviabiliza provar a ilegitimidade dessa apropriação.

A homenagem à obra também traz ambigüidades. Ao homenagear o outro, o escritor Ricardo Piglia também fana-o, no sentido duplo de amputar, cortar e consagrar, dedicar. Por isso, o próprio texto de homenagem é um texto de cortes, supressões, eliminações, ao fingir-se um RESUMO.

Poder-se-ia dizer acerca dessa maquinaria literária do Nome falso - é um "bulário",
ILZA MATIAS DE SOUZA é professora de Literatura, Lingua Portuguesa e Lingülstica na Universidade Federal de Minas Gerais.

Acima, Marilyn Monroe, de Andy Warhol; óleo sobre tela de 1962 
escritinho. Coleção de bulas (burlas?!), glosas, anotações marginais, investigação da palavra obscura. O editor, o divulgador e informante da obra de Arlt são papéis falsificadores. Nome falso constrói-se como simulacro, sem representação. Não há substituição do herdeiro falecido pelos respectivos herdeiros do seu legado literário, porque não há representantes nem direitos legais de representados. A operação de fundar a representação não tem, assim, mais sentido. $\mathrm{O}$ resumo feito por Piglia do material literário de Arlt é em si uma burla, pois esta já se encontra dilứda, desfeita. O jogo da escritura desfaz os modelados, as representações, por meio de modelos.

Pretendente falso, o simulacro é uma maquinaria simbólica. Transcrição, cópia, potencialmente ilimitada, a atividade escritural produz "cópia de uma infinidade de copias". Não deixa subsistir original nem mesmo origem. "Cada coisa, animal ou ser ê levado ao estado de simulacro, de signo" (Deleuze).

A imagem constituída por esse simulacro - a do autor Roberto Arlt e sua obra ficcional conhecida e inédita - está vinculada afetivamente ao objeto do amor real: o escritor argentino Roberto Arlt, seus textos, seu legado literário, enfim. A publicação do trabalho sobre o escritor é a publicação do trabalho do autor, sob nome falso. Produz um simulacro, um ídolo, uma falsificação.

Release e script, Nome falso é um modo de escrevinhação. O escrevinhador rabisca a escritura de outrem, a partir de uma diferença constitutiva - o distanciamento do real e do verdadeiro. $\mathrm{O}$ outro $\mathrm{e} o$ texto do outro são ambos fabricação imaginária. A sua existência nasce no seu comércio com o mundo do dinheiro. É o tornar-se mercadoria da obra de arte (falam Lukács e W. Benjamin). Nesse aspecto, Piglia ultrapassa os limites da "literariedade" para exercer um trabalho de crítica das relações da escrita com as instituições da sociedade e o poder, hoje, quando o artista deve fabricar objetos que devem ser vendidos.

Sem representação, a escrita de Piglia só pode estar sob nome falso. Ao inventariar e organizar a obra de Arlt, a fim de exibi-la numa edição comemorativa, Piglia transcreve-a. Esse ato é a execução de uma escrita simultânea. Inscreve-se numa história da infâmia. Escrita infamante, invenção de sua própria imprensa. A inconsistência da imagem de Arlt é a do pastiche: imitação falsa, oscilante, entre o genial e o idiota, o grande escritor e o escritor fracassado. Composição sobre uma disparidade: a produção de simulacros, falsos imitadores. "Os homens que vejo pela janela não são manequins?" (Descartes).

O pastiche é a forma sutil e elaborada dessa falsificação. Lança-se no paradoxo. Constitui-se paralogismo. Coloca em jogo o indecidível. É verdadeiro ou falso? Está-se diante de uma excelente imitação dos textos de Roberto Arlt? Trata-se de uma falsificação feita por um copista tecnicamente qualificado, Ricardo Piglia?

$\mathrm{O}$ pastiche e as formas do simulacro foram deslegitimados em seu valor criativo por uma longa tradição. A sua concepção ficou vinculada a um dado de servilidade do autor que pasticha ao objeto pastichado. Esse traço está na definição corrente: obra literária ou artística imitada servilmente de outro. Ou, num sentido pejorativo: imitação ruim de uma obra literária.

No movimento desconstrutor promovido desde a modernidade, a mimese e a representação têm seus fundamentos desconstituídos em seu valor de verdade, realismo ou verossimilhança. As artes são produção de simulacros. O quadro, por exemplo, revelase simulacro de um objeto fabricado pelo homem. A simulação ou a arte da cópia postas em circulação, o pastiche com seu objeto heterogêneo tomam a forma crítica da autoria, da originalidade, individualidade e uniformidade da obra.

Do lugar de onde escreve, Piglia pratica o pastiche, fora de relações de dominação e servidão. Executa o seu processo de produção numa forma questionante. Introduz o seu traço - verídico ou falso (não interessa) - de homem de letras, na escolha e na composição, a fim de produzir efeitos de MIX, com uma qualidade técnica e artística de mixador de várias peças literárias. Piglia parece considerar o trabalhador literário uma categoria não mais individualizada no sistema de produção da riqueza. Derruba os privilégios das profissões. Faz da cultura argentina o alimento de sua maquinaria. Promove o intercâmbio literário. Realiza um trabalho refinado, extraindo uma inovadora e criativa posição literária, na pluralidade de textos, escritores e escrituras.

A edição comemorativa da obra de Roberto Arlt é uma montagem maquínica de Ricardo Piglia. Um infatigável trabalho de investigação de um objeto amoroso e volúvel. Assume direções desviantes assinaladas com pistas falsas e faz da burla a economia da criação, do jogo e da elaboração. 